\title{
Retrospective Evaluation of Intoxication Cases Followed in Pediatric Intensive Care: A 5-Year Experience
}

\author{
Muhterem Duyu1, Şeyma Köksal Atış² \\ ${ }^{1}$ Department of Pediatrics, Pediatric Intensive Care Unit, Istanbul Medeniyet University, Goztepe Training and Research \\ Hospital, Istanbul, Turkey \\ 2Department of Pediatrics, Istanbul Medeniyet University, Goztepe Training and Research Hospital, Istanbul, Turkey
}

\begin{abstract}
Introduction: This study was designed to investigate the demographic, epidemiologic and clinical characteristics of cases admitted to the pediatric intensive care unit (PICU) with a diagnosis of intoxication.

Methods: Inpatient intoxication cases who were treated in the PICU between May 2015 and May 2020 were analyzed retrospectively.

Results: A total of 86 patients were included in the study. The average age was $10.8 \pm 6.4$ years and $53.5 \%$ of the cases were aged between 13-18 years. In terms of gender, $48.8 \%$ of the cases were male. Almost half of the (53.5\%) intoxications occurred due to attempted suicide, $39.6 \%$ were accidental, $4.6 \%$ were due to substance abuse and $2.3 \%$ were due to incorrect drug dosage. Pharmaceutical agents were responsible for intoxication in the majority (79.1\%) of patients, and among these, central nervous system (CNS) drugs were the most common (41.8\%). Carbon monoxide poisoning was the most common nonpharmaceutical agent cause (8.1\%). The agents that caused the intoxication were taken orally in $91.8 \%$ of cases. The average time from consumption to admission was $239 \pm 423.9$ minutes. Gastric lavage was applied to $41.9 \%$ of the cases and activated charcoal was applied to $44.1 \%$. Mechanical ventilation support was given to $32.6 \%$ of the patients. The most common findings were CNS symptoms (in $54.6 \%$ of patients). The mean length of stay (LOS) in PICU was $4.3 \pm 6.7$ days and LOS in the hospital was $5.8 \pm 7.1$ days. Mortality rate was $1.2 \%$.

Discussion and Conclusion: Knowing the epidemiology of intoxication is of great importance for rapid and correct treatment. Multicenter comprehensive studies are needed to reveal risk factors related to mortality.

Keywords: Drug; intoxication; pediatric intensive care; suicide.
\end{abstract}

I ntoxication is common in the childhood and represents one of the preventable causes of mortality and morbidity. It remains among the leading causes of hospitalization throughout the world ${ }^{[1,2]}$. Although progress has been made in the prevention of accidental intoxications, the utilization of better packaging techniques and increasing awareness regarding the composition of toxic products is crucial, since intoxication are still frequent in children, particularly in those aged 2 to 3 years old ${ }^{[3]}$. In 2017, the " $35^{\text {th }}$ Annual Report of the American Association of Poison Control Centers, National Poison Data System" recorded more than two million calls concerning cases of human exposure to toxic substances. Among these more than $50 \%$ were due to acute intoxications in children under 13 years of age ${ }^{[4]}$.

Correspondence (İletişim): Muhterem Duyu, M.D. Istanbul Medeniyet Universitesi, Goztepe Egitim ve Arastirma Hastanesi, Cocuk Sagligi ve Hastaliklari, Cocuk Yogun Bakim Unitesi, Istanbul, Turkey

Phone (Telefon): +90 5556745661 E-mail (E-posta): drmuhteremduyu@gmail.com

Submitted Date (Başvuru Tarihi): 06.07.2020 Accepted Date (Kabul Tarihi): 07.09.2020

Copyright 2020 Haydarpaşa Numune Medical Journal

OPEN ACCESS This is an open access article under the CC BY-NC license (http://creativecommons.org/licenses/by-nc/4.0/) 
According to the 2008 report of the "National Poison Counseling Center (Ulusal Zehir Danışma Merkezi, UZEM)", $60.1 \%$ of the 77.988 intoxication cases in Turkey were younger than 19 years old, and $52.8 \%$ of these were recorded in children younger than 5 years ${ }^{[5]}$.

Although most cases of intoxication in children are asymptomatic at admission, some may have life-threatening symptoms. In the presence of such symptoms, children should be admitted to and treated in the pediatric intensive care unit (PICU) ${ }^{[6]}$. Although a previous study by Patel et al. ${ }^{[7]}$ reported that approximately $70 \%$ of the 12.021 patients who had been admitted to the PICU did not require any major medical intervention, there is currently no reliable scoring system to predict patients who will need intensive care after acute intoxication. Therefore, many cases with intoxication are admitted to the PICU even when they do not have symptoms.

The epidemiology of childhood intoxication varies from country to country. It is also well-established that regional, socio-cultural and economic characteristics within the same country are also influential on epidemiological findings ${ }^{[8,9]}$. Therefore, every country and region should carry out epidemiological investigations in order to be able to implement accurate preventive interventions.

The aim of this study is to retrospectively evaluate the demographic and epidemiological characteristics and the clinical features and prognoses of patients who received inpatient treatment in our PICU within the 5-year study period.

\section{Materials and Methods}

A total of 86 patients, aged from 1 month to 18 years old, treated for acute intoxication at the PICU of Istanbul Medeniyet University, Goztepe Training and Research Hospital in Istanbul, Turkey, between May 2015 and May 2020 were included in this study. Patient files were scanned for age, gender, Pediatric Risk of Mortality III (PRISM III) score and Glasgow Coma Scale (GCS) score (at admission), type of intoxication (suicidal purpose, accidental, substance abuse, dosage error), route of intoxication (ingestion/oral, inhalation/nasal), medical interventions related to intoxication (minor interventions, gastric lavage, activated charcoal, mechanical ventilation [MV], renal replacement treatment [RRT], plasmapheresis, cardiac pacing, extracorporeal membrane oxygenation [ECMO], hyperbaric oxygen therapy, inotrope drug administration), length of stay (LOS) in PICU, LOS in hospital, and survival.

Interventions such as continuous monitoring, intra- venous fluid administration and laboratory follow-up were recorded as minor interventions. Patients with missing and/ or inaccessible records and cases hospitalized in the PICU due to food intoxication were not included in the study.

The agents causing intoxication were divided into two groups as pharmaceutical and non-pharmaceutical agents. The number of agents were classified as single and multiple. Pharmaceutical agents responsible for intoxication were divided into the following drug groups according to their effect spectrum: central nervous system (CNS) drugs, analgesics and antipyretics, cardiovascular and antihypertensive drugs, antihistaminics and antiemetics, immunosuppressive and oncological drugs, antimicrobials, muscle relaxants, hormones and hormone antagonists, and others. All signs of intoxication observed in the patient were recorded. Intoxication findings were classified as follows: CNS, gastrointestinal system, cardiovascular system, respiratory system, and metabolic/biochemical findings.

Approval for the study was obtained from the local ethics committee (Protocol number: 2020/0336). The study was conducted in accordance with the principles of the Declaration of Helsinki.

\section{Statistical Analysis}

Data were evaluated using SPSS version 18.0 (SPSS, Inc., Chicago, IL). Categorical variables were presented as frequency and percentage. Continuous variables were presented as mean \pm standard deviation, and minimum ( $\mathrm{min}$ ) and maximum (max) values.

\section{Results}

A total of 94 cases were hospitalized in our PICU between May 2015 and May 2020 due to intoxication (4 cases were excluded from the study due to lack of patient records and 4 cases due to food intoxication). Detailed clinical and demographic characteristics of the patients included in the study are presented in Table 1. The average age of the patients included in the study was $10.8 \pm 6.4$ years. The majority of the cases (53.5\%) were between 13-18 years old. In terms of gender, $48.8 \%$ of the cases were male, and $57.5 \%$ of the cases under 5 years of age were male. The mean PRISM III score of the cases was $4.3 \pm 4.2$ and the mean GCS score was $11.7 \pm 4.0$.

Among the causes of intoxication, suicide attempts were the most common (53.5\%), followed by accidents (39.6\%), substance abuse (4.6\%) and dosage errors (2.3\%). The most common cause of intoxication in cases under 5 years of age was accidental drug in-take (94.0\%). Suicidal purpose was 
Table 1. Clinical and demographic characteristics of acute intoxication cases and distribution of treatment methods

\begin{tabular}{|c|c|}
\hline Characteristics & Value \\
\hline $\begin{array}{l}\text { Age at admission (year), } \\
\text { mean } \pm S D \text { (min-max) }\end{array}$ & $10.8 \pm 6.4(0.5-18)$ \\
\hline \multicolumn{2}{|l|}{ Age distribution (year), $\mathrm{n}(\%)$} \\
\hline$<5$ & $33(38.4)$ \\
\hline $6-12$ & $7(8.1)$ \\
\hline $13-18$ & $46(53.5)$ \\
\hline \multicolumn{2}{|l|}{ Gender } \\
\hline Male, n (\%) & $42(48.8)$ \\
\hline Female, n (\%) & $44(51.2)$ \\
\hline $\begin{array}{l}\text { PRISM III at admission to the PICU, } \\
\text { mean } \pm \text { SD (min-max) }\end{array}$ & $4.3 \pm 4.2(1-19)$ \\
\hline $\begin{array}{l}\text { GCS at admission to the PICU, } \\
\text { mean } \pm \text { SD (min-max) }\end{array}$ & $11.7 \pm 4.0(4-15)$ \\
\hline \multicolumn{2}{|l|}{ Cause of poisoning, $\mathrm{n}(\%)$} \\
\hline Suicide purpose & $46(53.5)$ \\
\hline Accidentally & $36(39.6)$ \\
\hline Substance abuse & $4(4.6)$ \\
\hline Dosage error & $2(2.3)$ \\
\hline \multicolumn{2}{|l|}{ Route of exposure, n (\%) } \\
\hline Ingestion/oral & $79(91.8)$ \\
\hline Inhalation/nasal & $7(8.2)$ \\
\hline \multicolumn{2}{|l|}{ a⿳Medical intervention, n (\%) } \\
\hline Activated charcoal & $38(44.1)$ \\
\hline Gastric lavage & $36(41.9)$ \\
\hline Mechanical ventilation & $28(32.6)$ \\
\hline Minor interventions & $21(24.4)$ \\
\hline Renal replacement treatment & $6(6.9)$ \\
\hline Plasmapheresis & $3(3.5)$ \\
\hline Cardiac pacing & $1(1.2)$ \\
\hline Extracorporeal membrane oxygeation & $1(1.2)$ \\
\hline Hyperbaric oxygen therapy, n (\%) & $3(3.5)$ \\
\hline İnotrope drug administration, n (\%) & $3(3.5)$ \\
\hline $\begin{array}{l}\text { Duration of time from exposure to } \\
\text { admission the hospital (min), } \\
\text { mean } \pm S D \text { (min-max) }\end{array}$ & $239.0 \pm 423.9(15-2880)$ \\
\hline $\begin{array}{l}\text { Length of PICU stay (day), } \\
\text { mean } \pm \text { SD (min-max) }\end{array}$ & $4.3 \pm 6.7(1-50)$ \\
\hline $\begin{array}{l}\text { Length of hospital stay (day), } \\
\text { mean } \pm S D \text { (min-max) }\end{array}$ & $5.8 \pm 7.1(1-50)$ \\
\hline Survival, n (\%) & $85(98.8)$ \\
\hline
\end{tabular}

PRISM: Pediatric risk of mortality, GCS: Glasgow coma score, PICU: Pediatric intensive care unit, SD: Standart derivation; ${ }^{\text {a: }}$ More than one medical intervention was performed to 40 patients.

the cause of intoxication in $89.1 \%$ of cases over the age of 13 years. Of the 46 suicide cases, 36 (78.2\%) were female. The most common route of exposure to intoxication was the ingestion/oral route $(91.8 \%)$. The distribution of med- ical interventions for intoxication are presented in Table 1. Activated charcoal was applied to $44.1 \%$ of patients and gastric lavage was applied to $41.9 \%$ of subjects. Need for MV developed in $32.6 \%$ of the patients, while $24.4 \%$ of the individuals had only received minor interventions. Of the 6 patients $(7.0 \%)$ who underwent RRT, two cases were anticonvulsant drug (carbamazepine) intoxication, two were metformin intoxication, one was alcohol intoxication and one was methamphetamine intoxication. Of the 3 (3.5\%) cases who underwent plasmapheresis, 2 were colchicine intoxication and 1 was isoniazid intoxication. Cardiac pacing was performed in 1 case (1.2\%) due to symptomatic bradycardia caused by beta-blocker intoxication. ECMO treatment was applied to 1 case for acute respiratory distress syndrome (ARDS) that had developed due to activated charcoal aspiration. All of the cases who were treated with hyperbaric oxygen therapy (3.5\%) were cases of carbon monoxide intoxication.

The average time between exposure to the agent causing intoxication and admission to the hospital was $239 \pm 423.9$ minutes. In cases with suicidal purpose, the time to admission was $276.5 \pm 500.5$ minutes. The mean LOS in PICU was $4.3 \pm 6.7$ days, and the average LOS in the hospital was $5.8 \pm 7.1$ days. Survival rate was $98.8 \%$. Only 1 case (1.2\%) died, caused by intoxication with calcium channel blocker.

Detailed analysis of the agents causing intoxication is presented in Table 2 . The majority (67.4\%) of the patients had single-agent intoxication and $32.6 \%$ had multiple-agent intoxication. $39.7 \%(23 / 58)$ of single-agent intoxication cases were under 5 years old, while $69.7 \%$ (23/33) of the patients younger than 5 years old had single-agent intoxication.

Pharmaceutical agents were responsible in $79.1 \%$ of patients. CNS drugs were responsible in $41.8 \%$ of the patients, followed by analgesics and antipyretics $(16.3 \%)$, cardiovascular and antihypertensive drugs (10.5\%), antihistaminics and antiemetics (10.5\%), immunosuppressive and oncological drugs (9.3\%) and antimicrobials (6.9\%). Non-pharmaceutical intoxication was present in $20.9 \%$ of individuals with carbon monoxide being the leading cause (8.1\%).

The clinical findings of intoxication are presented in Table 3. The vast majority of patients (82.6\%) had some form of clinical or metabolic/biochemical findings. More than one finding was present in $20.9 \%$ of the patients. The most common among these were CNS symptoms in $54.6 \%$ of patients and the most common CNS findings was confusion/ tendency to sleep seen (in $29.0 \%$ of subjects). CNS findings were followed by gastrointestinal system findings (14.0\%), 
Table 2. Detailed analysis of intoxication agents

\begin{tabular}{|c|c|}
\hline Characteristics & Value, n (\%) \\
\hline \multicolumn{2}{|l|}{ Number of agents exposed } \\
\hline Single agent intoxication & $58(67.4)$ \\
\hline aMultiple agent intoxication & $28(32.6)$ \\
\hline \multicolumn{2}{|l|}{ Intoxication type } \\
\hline Pharmaceuticals Agents & $68(79.1)$ \\
\hline Nonpharmaceuticals Agents & $18(20.9)$ \\
\hline \multirow{2}{*}{\multicolumn{2}{|c|}{$\begin{array}{l}\text { Distribution of intoxication agents } \\
\text { apharmaceuticals Agents }\end{array}$}} \\
\hline & \\
\hline $1-{ }^{b}$ Central nervous system drugs & $36(41.8)$ \\
\hline Antipsychotics & $22(25.6)$ \\
\hline Antidepressants & $17(19.8)$ \\
\hline Anticonvulsants & $12(14.0)$ \\
\hline Benzodiazepines & $5(5.7)$ \\
\hline Psycostimulants & $2(2.3)$ \\
\hline 2- ${ }^{\mathrm{b}}$ Analgesics and antipiretics & $14(16.3)$ \\
\hline Paracetamol & $13(15.2)$ \\
\hline NSAID drugs & $5(5.7)$ \\
\hline Aspirin & $2(2.3)$ \\
\hline 3- bCardiovascular/ antihypertensive drugs & $9(10.5)$ \\
\hline Beta blockers & $5(5.7)$ \\
\hline Calcium canal blockers & $3(3.5)$ \\
\hline ACEI & $2(2.3)$ \\
\hline Klonidine & $1(1.2)$ \\
\hline 4- ${ }^{\mathrm{b}}$ Antihistamines/antiemetics & $9(10.5)$ \\
\hline 5- ${ }^{\text {Immunsuppresive/oncologic drugs }}$ & $8(9.3)$ \\
\hline Colchicine & $6(6.9)$ \\
\hline Azathiopurine & $1(1.2)$ \\
\hline Methotrexate & $1(1.2)$ \\
\hline 6- ${ }^{\mathrm{b}}$ Antimicrobials & $6(6.9)$ \\
\hline Isoniazid (INH) & $4(4.6)$ \\
\hline Others & $2(2.3)$ \\
\hline 7- buscle relaxants & $3(3.5)$ \\
\hline 8- bHormones and hormone antagonists & $2(2.3)$ \\
\hline 9- ${ }^{b}$ Others & $10(11.6)$ \\
\hline Electrolytes/minerals/vitamins & $4(4.6)$ \\
\hline Iron derivatives & $4(4.6)$ \\
\hline Metformin & $3(3.5)$ \\
\hline Salbutamol & $1(1.2)$ \\
\hline Nonpharmaceuticals agents & $18(20.9)$ \\
\hline Carbon monoxide & $7(8.1)$ \\
\hline Cosmetics/household cleaning products & $2(2.3)$ \\
\hline Cannabinol & $2(2.3)$ \\
\hline Metamfetamine & $2(2.3)$ \\
\hline Alcohol & $2(2.3)$ \\
\hline Hydrocarbons & $1(1.2)$ \\
\hline Rat Poison & $1(1.2)$ \\
\hline Activated charcoal & $1(1.2)$ \\
\hline
\end{tabular}

NSAID: Nonsteroidal anti-inflammatory drugs, ACEl: Angiotensinconverting enzyme inhibitors. ${ }^{\text {a: }}$ All 28 cases exposed to multiple agent intoxication are from the group of pharmaceuticals agents. ${ }^{b}$ : The rates and percentages in the drug groups and subgroups were calculated among all patients $(n=86)$ included in the study.
Table 3. Detailed analysis of findings related to intoxication

\begin{tabular}{lc}
\hline Variable & Value, $\mathbf{n}(\mathbf{\%})$ \\
\hline Symptom & \\
Present & $63(82.6)$ \\
Absent & $15(17.4)$ \\
>1 symptom presence & $18(20.9)$ \\
Distribution of findings at admission & \\
a'Central nervous system findings & $47(54.6)$ \\
Confusion/tendency to sleep & $25(29.0)$ \\
Convulsion & $9(10.4)$ \\
Coma (GCS $\leq 8)$ & $7(8.1)$ \\
Agitation & $3(3.5)$ \\
Dystonia & $2(2.3)$ \\
Mydriasis & $2(2.3)$ \\
Hypersalivation & $2(2.3)$ \\
Rigidity & $1(1.2)$ \\
Dysarthria & $1(1.2)$ \\
Myoclonus & $1(1.2)$ \\
Syncope & $1(1.2)$ \\
aGastrointestinal system findings & $12(14.0)$ \\
Vomiting & $7(8.1)$ \\
Abdominal pain & $5(5.8)$ \\
Diarrhea & $2(2.3)$ \\
aardiovascular system findings & $8(9.3)$ \\
Hypotension & $4(4.6)$ \\
Tachycardia & $3(3.5)$ \\
Bradycardia & $3(3.5)$ \\
Respiratory system findings & $7(8.1)$ \\
Tachypnea & $7(8.1)$ \\
Hetabolic/biochemical findings & $1(1.2)$ \\
Hypoglycemia & $8(9.3)$ \\
\hline
\end{tabular}

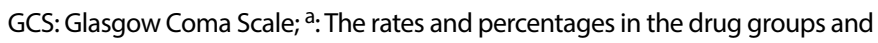
subgroups were calculated among all patients $(n=86)$ included in the study.

cardiovascular system findings (9.3\%) and respiratory system findings (8.1\%). Metabolic/biochemical findings were present in $9.3 \%$ of the cases. The most common of these were metabolic acidosis (7.0\%) and lactic acidosis (3.5\%).

\section{Discussion}

The aim of this study was to investigate the demographic and clinical characteristics of pediatric patients admitted to the PICU due to acute intoxication. The analysis of the literature showed the presence of numerous studies on this 
topic. It is evident that this issue has been frequently investigated due to its importance and the need for localized studies.

Intoxications can occur accidentally or with suicidal purposes. The data from studies conducted in our country have reported a frequency of accidental poisoning from $53.7 \%$ to $90.0 \%$, and suicidal poisoning from $8.2 \%$ to $46.3 \%[8,10-$ 13]. In our study, $53.5 \%$ of intoxications had occurred due to attempted suicide, $41.9 \%$ were accidental and $4.6 \%$ were due to substance abuse. When the distribution of intoxication cases in the literature were examined based on the gender and age, it was observed that male children were more likely to suffer from accidental intoxications at a younger age, whereas a higher rate of suicidal intoxications was observed in girls of pubertal age ${ }^{[14-16]}$. Concurrently, intoxication was more common in boys under the age of 5 , and girls older than 13. Similar to the literature, the cause of intoxication was mostly accidental (94.0\%) in cases under 5 years of age, and mostly suicidal purposes (89.1\%) in patients older than 13 years of age in our study.

The age and gender distribution of intoxication cases varies from country to country and center to center. In our study, $38.4 \%$ of the patients were under 5 years old, and $51.2 \%$ of our cases were girls. The literature shows varying levels of gender distribution with slight differences $[8,10,11$, $17,18]$. The average age of childhood intoxication cases in our country has been reported to vary between 5.2 years and 8.4 years $^{[8,12,18,19]}$. In our study, the average age of intoxication cases considerably higher than prior publications from our country (10.8 \pm 6.4 years). It was thought that this difference could be due to the variations in the criteria for admission to the PICU, which may have favored a higher likelihood of PICU admission in older patients with suicidal intent.

In our study, the mean PRISM III score was $4.3 \pm 4.2$ and the mean GCS score was $11.7 \pm 4.0$ at PICU admission. In the study conducted by Keskin et al. patients were divided into two groups: those with and those without indication for intensive care admission. Patients who were admitted to intensive care were found to have higher PRISM III score and lower GCS score than the other group ${ }^{[18]}$. In a multicenter study conducted in the USA, mortality was associated with high PRISM III score in a group of 12.021 intoxication cases followed in the PICU[7]. Currently, there are no clinical tools or scales that enable the prediction of PICU requirement after acute intoxication. Usually, intoxication control centers advise PICU admission in almost all pediatric intoxication cases. However, this is not possible in the majority of pediatric clinics all over the globe. To our knowledge, there is only one single-center observational study comprised of 2.565 adult patients which found that the GCS score was the only predictor for intensive care unit admission in adults ${ }^{[20]}$. The ideal predictive model should be able to determine which children examined in the emergency room, regardless of presentation severity, are at risk for later deterioration and thus should be admitted to the PICU for observation of potentially life-threatening complications following an acute intoxication. High-risk cases can be identified by developing scoring systems and criteria for investigation in the intensive care setting with multi-center studies in children. In this way, efficient use of PICU beds can be achieved.

Turkish studies on intoxication report that the route of intoxication in the ingestion/oral route in over $90 \%{\text { of } \text { cases }^{[8,}}^{[8,}$ 11], similar to our results. The type and distribution of childhood intoxication (pharmaceuticals vs. non-pharmaceuticals) vary according to the country, geographical region and socio-cultural and economic level. Results vary depending on whether studies are carried out in the pediatric emergency department or in the PICU. Gokalp et. al., from Turkey, demonstrated that the majority of intoxication cases in the pediatric emergency department were caused by non-pharmaceutical agents -mostly household cleaning products $(62.9 \%)^{[19]}$. In a multi-center study conducted in Italy, 59.0\% of the patients were reported to have been intoxicated with non-pharmaceutical agents, and among these agents the most common were household cleaning products $(49.0 \%)^{[21]}$. In studies conducted in PICUs, the situation was different. Intoxication with pharmaceutical agents were found at a higher frequency, with rates ranging from $60.2 \%$ to $81.7 \%[8,13]$. Similarly, intoxication with pharmaceutical agents were observed in $79.1 \%$ of our patients.

The types of drugs that cause intoxication vary according to country, socio-economic status and cultural differences. In the study conducted by Berta et al. from Italy, the most common pharmaceutical agents causing intoxication were listed as analgesics, psychotropics and cardiovascular agents ${ }^{[21]}$. In studies conducted in Turkey, CNS drugs, anal-

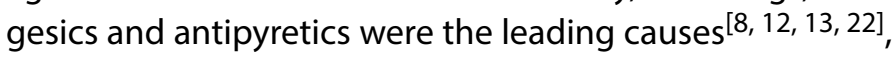
exemplified by our results. These were followed by cardiovascular and antihypertensive drugs and antihistamines and antiemetics.

Intoxication caused by non-drug substances also vary according to geographical region, socio-economic status and time of year (in relation with season). Kendirci et al. found 
that $49 \%$ of their cases had carbon monoxide intoxication in their study, which was associated with the low socio-economic level of the region served by the hospital and the use of coal stoves in homes ${ }^{[22]}$. Kızılyıldız et al. found that pesticides were the most common cause of intoxication with non-drug substances in their studies in Van, Turkey ${ }^{[23]}$. In another study in Italy, it was reported that the most common non-drug agents were household cleaning products [21]. In our study, the most common non-pharmaceutical agent causing intoxication was found to be carbon monoxide poisoning (8.1\%).

Drug intoxication may develop due to one type of agent, or it may develop due to the intake of more than one agent. In the study by Berta et al., only $4.8 \%$ of patients had intoxication with multiple agents. In this study, patients with single-agent intoxication were found to be younger than those with multiple-agent intoxication (median, 2.1 vs. 3.5 years) ${ }^{[21]}$. Yorulmaz et al. showed that the majority (80.1\%) of the intoxication cases admitted to the pediatric emergency department were due to a single agent ${ }^{[12]}$. In our study, most of the patients (67.4\%) were exposed to intoxication with one type of agent, and $39.7 \%$ of single-agent intoxication cases were in patients younger than 5 years of age. $69.7 \%$ of patients under 5 years of age were found to have single-agent intoxication.

Post-intoxication treatments can be summarized as follows: prevention or reduction of the absorption of the toxic substance from the gastrointestinal tract, skin and other routes, administration of antidotes, altering metabolism of the toxic substance, accelerating excretion, detoxification, and supportive treatments with extracorporeal methods $[7$, 24]. In the literature, gastric lavage, activated charcoal, and mechanical ventilator support are listed as the most common medical interventions in intoxication cases ${ }^{[8,10,12]}$. In our study, gastric lavage was applied to $41.9 \%$ of the patients and activated charcoal was applied to $44.1 \%$-similar to the literature on this topic.

Some of our patients were treated with extracorporeal management methods. RRT was applied in 6 patients in total. The agents were: anticonvulsive-drug (carbamazepine) in two, metformin in two, alcohol in one and methamphetamine in one. In metformin and alcohol intoxication, RRT can be applied for the treatment of severe metabolic $\operatorname{acidosis}^{[25,26]}$. Although rare, methamphetamine intoxication has been reported to cause acute kidney failure ${ }^{[27]}$. In severe carbamazepine intoxication, RRT was recommended due to the high binding capacity of the drug to plasma proteins ${ }^{[28]}$. Another extracorporeal method we practiced was plasmapheresis which was utilized in three patients. Two of the patients had colchicine and 1 had isoniazid poisoning. In the case with isoniazid intoxication, plasmapheresis was required due to the development of acute liver failure. There are publications in the literature reporting that plasmapheresis therapy may have beneficial effects on colchicine intoxication ${ }^{[29]}$. Plasmapheresis treatment was applied in these two cases because colchicine intake was at a major toxic level. In one case, cardiac pacing was performed because of hypotension that was resistant to inotropic therapy (toxic dose beta blocker intoxication). ECMO treatment was applied to one case for the treatment of ARDS that had developed due to activated charcoal aspiration. Although activated charcoal is an inert substance, it is an agent that can cause serious damage to the lung with an inflammatory effect when aspirated ${ }^{[30]}$.

Intoxication-related findings depend on the agent causing intoxication, the amount of the agent taken and the time between intoxication and hospital admission. The frequency of the presence of intoxication-related clinical findings at the time of admission (to the emergency room) and PICU admission have been reported to be $28.7 \%$ and $72.1 \%[8,10-12]$. In our study, the majority of patients (82.6\%) had at least one toxicity-related finding. This may be due to the lower frequency of symptoms in patients admitted to the emergency department. Another reason was the acceptance criteria to PICU, which may have caused some exaggeration of findings due to the fear of toxic effects in relation to the type and/or dosage of the agent taken. The most common finding observed in our patients were CNS findings, and $54.6 \%$ of the patients had at least one neurological finding. CNS findings were followed by gastrointestinal system findings with $14.0 \%$ of patients having at least one gastrointestinal system finding. In the literature, although the findings of the gastrointestinal tract are more frequent, CNS findings are often in second place in terms of frequency ${ }^{[8,10-12]}$.

The period between intoxication and hospital admission is very important for decontamination procedures after intoxication and also the initiation of appropriate treatment. In our study, the average time from intoxication to hospital admission was 239 minutes. In various studies reported from our country, this time ranged from 89 to 223 minutes on average ${ }^{[8,11,12]}$.

Studies have shown that the average duration of PICU stay in intoxication cases ranged from 20 hours to 2 days ${ }^{[8,11-}$ $13,18,24]$ and the average hospital stay from 20 hours to 3.5 days $[8,11,13,18,31]$. In our study, mean LOS at PICU was 4.3 
days and mean LOS at hospital was 5.8 days. In our country, mortality rates due to intoxication vary between $0 \%$ and $5.4 \%$ in the pediatric age group ${ }^{[8,10-13,22]}$. In the literature, the largest study evaluating intoxication cases in PICUs belongs to Patel et al. with 12.021 cases with a mortality rate of $0.6 \%{ }^{[7]}$. In our study, the mortality rate was $1.2 \%(n=1)$. The death was associated with refractory shock by calcium channel blocker intoxication. Previous studies from our country were unable to evaluate risk factors associated with mortality, since mortality rate is low and the majority of studies were performed in a single-center with limited number of patients. There is a need for multicenter studies to reach a wide range of cases.

There were some study limitations that must be discussed. Since this was a retrospective study, the long-term results of the patients are unknown. Secondly, it is not possible to generalize our findings to the entire pediatric age group, since our study only included cases admitted to the PICU. Finally, it was not possible to evaluate mortality-related risk factors due to small sample size -as is the case in the majority of studies in this field.

\section{Conclusions}

Childhood intoxications are one of the most important causes of preventable mortality and morbidity throughout the world. Knowing the epidemiology of intoxication is of great importance for rapid and correct treatment. Multicenter comprehensive studies are needed to reveal risk factors related to mortality. The development of clinical scoring tools that can predict which patients may require intensive care will increase the efficiency of PICU utilization.

Ethics Committee Approval: Approval of the study was obtained from the local ethics commitee (Protocol number: 2020/0336). The study was conducted in accordance with the principles of the Declaration of Helsinki.

Peer-review: Externally peer-reviewed.

Authorship Contributions: Concept: M.D., Ş.K.A.; Design: M.D.; Data Collection or Processing: Ş.K.A.; Analysis or Interpretation: M.D.; Literature Search: M.D.; Writing: M.D.

Conflict of Interest: None declared.

Financial Disclosure: The authors declared that this study received no financial support.

\section{References}

1. Lingeswaran A. Patterns of accidental intoxication in children in Puducherry, India. Indian J Res 2016;5:301-2.

2. Kyu $\mathrm{HH}$, Stein CE, Pinto CB, Rakovac I, Weber MW, Purnat TD, et al. Causes of death among children aged 5-14 years in the WHO European region: a systematic analysis for the global burden of Desease study. Lancet Child Adolesc Health 2018;2:321-37. [CrossRef]

3. Nistor N, Frasinariu $\mathrm{OE}$, Rugină A, Ciomaga IM, Jităreanu C, Ştreangă V. Epidemiological study on accidental poisonings in children from northeast romania. Medicine (Baltimore). 2018;97:e11469. [CrossRef]

4. Gummin DD, Mowry JB, Spyker DA, Brooks DE, Osterthaler KM, Banner W. 2017 Annual Report of the American Association of Poison Control Centers' National Poison Data System (NPDS): 35th Annual Report. Clin Toxicol (Phila) 2018;56:1213-415.

5. Özcan N, İkincioğulları D. Ulusal zehir danışma merkezi 2008 yılı çalışma raporu özeti. Turk Hij Den Biyol Derg 2009;66:29_ 58.

6. Shannon M. Ingestion of toxic substances by children. N Engl J Med 2000;342:186-91. [CrossRef]

7. Patel MM, Travers CD, Stockwell JA, Geller RJ, Kamat PP, Grunwell JR. Analysis of Interventions Required in 12,021 Children With Acute Intoxications Admitted to PICUs. Pediatr Crit Care Med 2017;18:e281-e289. [CrossRef]

8. Ödek Ç, Akça H, Erol M, Demir R, Tunç M, Aydınalp A, et al. Çocuk Yoğun Bakım Ünitesinde Takip Edilen Zehirlenme OIgularının Demografik, Epidemiyolojik ve Klinik Özelliklerinin Geriye Dönük Değerlendirilmesi. J Pediatr Emerg Intensive Care Med 2019;6:72-8.

9. Bhat NK, Dhar M, Ahmad S, Chandar V. Profile of intoxication in children and adolescents at a North Indian tertiary care centre. JIACM 2011;13:37-42.

10. Akgül F, Er A, Çelik FÇ, Çağlar A, Ulusoy E, Yılmaz D, et al. Çocukluk çağı zehirlenmelerinin geriye dönük olarak incelenmesi. J Pediatr Emerg Intensive Care Med 2016;3:91-6. [CrossRef]

11. Akin Y, Ağzikuru T, Cömert S, Atilkan P, Erdağ GC, Telatar B. Hospitalizations for pediatric intoxication: a study from İstanbul. Turk J Pediatr 2011;53:369-74. [CrossRef]

12. Yorulmaz A, Akbulut A, Yahya İ, Aktaş R, Emiroğlu EE, Peru $H$. Retrospective Evaluation of Patients Admitted to the Pediatric Emergency Department with Intoxicaition. J Pediatr Emerg Intensive Care Med 2017;4:96-103. [CrossRef]

13. Tekerek NÜ, Dursun A, Akyıldız BN. Çocuk yoğun bakım ünitesinde takip edilen zehirlenme olgularının geriye dönük değerlendirilmesi. J Pediatr Emerg Intensive Care Med 2016;3:21-6.

14. Ahmed A, AlJamal AN, Mohamed Ibrahim MI, Salameh K, AlYafei K, Zaineh SA, et al. Poisoning emergency visits among children: a 3-year retrospective study in Qatar. BMC Pediatr 2015;15:104. [CrossRef]

15. Mansori K, Soori H, Farnaghi F, Khodakarim S, Mansouri Hanis $S$, Khodadost M. A case-control study on risk factors for unintentional childhood poisoning in Tehran. Med J Islam Repub Iran 2016;30:355.

16. Hassan BA, Siam MG. Patterns of Acute Poisoning in Childhood in Zagazig, Egypt: An Epidemiological Study. Int Sch Res Notices 2014;2014:245279. [CrossRef]

17. Soyucen E, Aktan Y, Saral A, Akgün N, Numanoğlu AÜ. Sakarya 
bölgesinde çocukluk çağı zehirlenmelerinin geriye dönük değerlendirilmesi. Çocuk Sağlığı ve Hastalıkları Dergisi 2006;49:301-6.

18. Keskin H, Kara M, Akat H, Ceviz N. Pediatric Intoxication Cases Followed in the PICU; 2 year Experience. J Pediatr Emerg Intensive Care Med 2019;6:150-5. [CrossRef]

19. Gokalp G. Evaluation of poisoning cases admitted to pediatric emergency department. Int J Pediatr Adolesc Med 2019;6:109-14. [CrossRef]

20. Maignan M, Pommier P, Clot S, Saviuc P, Debaty G, Briot R, et al. Deliberate drug poisoning with slight symptoms on admission: are there predictive factors for intensive care unit referral? A three-year retrospective study. Basic Clin Pharmacol Toxicol 2014;114:281-7. [CrossRef]

21. Berta GN, Di Scipio F, Bosetti FM, Mognetti B, Romano F, Carere $\mathrm{ME}$, et al. Childhood acute poisoning in the Italian North-West area: a six-year retrospective study. Ital J Pediatr 2020;46:83.

22. Kendirci HNP, Çolakoğlu EY, Hızlı Ş, Koçak M, Saylam E, Polat $\mathrm{E}$, et al. Hastanemiz çocuk acil servisine başvuran zehirlenme olgularının değerlendirilmesi. Turkish J Pediatr Dis 2011;5:2935.

23. Kizilyildiz BS, Karaman K, Özen S, Üner A. Acute intoxications among Turkish children. Minerva Pediatr 2018;70:46-50.

24. Even KM, Armsby CC, Bateman ST. Poisonings requiring admission to the pediatric intensive care unit: A 5-year review. Clin Toxicol (Phila) 2014;52:519-24. [CrossRef]

25. Chen T, Zhu C, Liu B. Extracorporeal membrane oxygenation with continuous renal replacement therapy to treat metformin-associated lactic acidosis: A case report. Medicine (Baltimore) 2020;99:e20990. [CrossRef]

26. Mirrakhimov AE, Barbaryan A, Gray A, Ayach T. The Role of Renal Replacement Therapy in the Management of Pharmacologic Poisonings. Int J Nephrol 2016;2016:3047329. [CrossRef]

27. Bingham C, Beaman M, Nicholls AJ, Anthony PP. Necrotizing renal vasculopathy resulting in chronic renal failure after ingestion of methamphetamine and 3,4-methylenedioxymethamphetamine ('ecstasy'). Nephrol Dial Transplant 1998;13:2654-5. [CrossRef]

28. Ghannoum M, Yates C, Galvao TF, Sowinski KM, Vo TH, Coogan $A$, et al; EXTRIP workgroup. Extracorporeal treatment for carbamazepine poisoning: systematic review and recommendations from the EXTRIP workgroup. Clin Toxicol (Phila) 2014;52:993-1004. [CrossRef]

29. Ozdemir R, Bayrakci B, Teksam O. Fatal poisoning in children: acute colchicine intoxication and new treatment approaches. Clin Toxicol (Phila) 2011;49:739-43. [CrossRef]

30. Francis RC, Schefold JC, Bercker S, Temmesfeld-Wollbrück B, Weichert W, Spies CD, et al. Acute respiratory failure after aspiration of activated charcoal with recurrent deposition and release from an intrapulmonary cavern. Intensive Care Med 2009;35:360-3. [CrossRef]

31. Güzel IŞ, Kibar AE, Vidinlisan S. Çocuk acil servisine başvuran zehirlenme vakalarının demografik özelliklerinin incelenmesi. Genel Tıp Derg 2011;21:101-7. 